\title{
Effect of tool and operational parameters on performance of tillage implements
}

\section{Naveen Kumar and Ajay Kumar Sharma}

Received : $15.01 .2020 ;$ Accepted : 29.03 .2020

See end of the Paper for authors' affiliation

Correspondence to :

C. Naveen Kumar

Department of Farm Machinery and Power Engineering, College of Technology and Engineering, Maharana Pratap University of Agriculture and Technology, Udaipur (Rajasthan) India Email : naveenkumarc02@ gmail.com
- ABSTRACT : This article reviews the basic relationships between the soil parameters, tool geometry and operational parameters on the nature of soil disturbance and draft of the tillage tool. These relations will assist designers and operators of tillage implement or tillage tool in selecting the optimal design of the soil working elements and their supporting frame.

- KEY WORDS : Tool geometry, Operational parameters, Tillage tools, Soil disturbance, Rake angle, Draft

- HOW TO CITE THIS PAPER : Naveen Kumar, C. and Sharma, Ajay Kumar (2020). Effect of tool and operational parameters on performance of tillage implements. Internat. J. Agric. Engg., 13(1) : 145-154, DOI: 10.15740/HAS/IJAE/13.1/145-154. Copyright@ 2020: Hind Agri-Horticultural Society. 